\title{
Southeast Asian Public Perceptions of China: Clusters and Gaps
}

\author{
Yoonah Oh
}

This study offers an analysis of cross-country difference in Southeast Asian public opinion on China in the mid-2010s, using data from the Asian Barometer Survey (ABS). I pursue two empirical questions: (1) how China fared in perceived influence and positivity compared to the U.S. at the national level and (2) what perception gaps existed in regional and national assessments of China's positive impact. The findings indicate that public perceptions by country are not radically different from commonly known government-level orientations toward China. Yet there are interesting patterns of clusters across countries and gaps in perceptions. First, some countries consistently regard China more influential and more beneficial than the U.S. while others face a contradiction between China being more influential but less beneficial than the U.S. Second, in all countries, Southeast Asian respondents think that the extent to which China benefits their own country is greater than the extent to which China benefits the region, implying a potential collective action problem for a coherent regional response. It is also interesting to note that the largest perception gap is reported in the Philippines, the country at the forefront of the South China Sea disputes with China. The findings contribute to the larger literature on Southeast Asia's alignment choices in the face of the US-China strategic competition.

Keyword: Southeast Asia, China, public opinion, Asian Barometer, clusters, perception gaps

* Yoonah Oh/Yoon Ah Oh (yoonah.oh@snu.ac.kr) is an Assistant Professor at the Graduate School of International Studies, Seoul National University (SNU). She studies the intersection of politics, economics and policy in Southeast Asia. For the last few years, she has been examining the geopolitical aspect of Southeast Asia's economic relations with China. Prior to joining SNU, she was a fellow at the Korea Institute for International Economic Policy, where she conducted research on Southeast Asian economies and Korea-ASEAN economic relations.

The author would like to thank the three anonymous reviewers for providing helpful and constructive comments and the Asian Barometer Survey (ABS) for granting access to the data used in this study.

This work was supported by the New Faculty Startup Fund from Seoul National University.

The Korean Journal of International Studies Vol.19, No.3 (December 2021), 377-403 


\section{INTRODUCTION}

Popular accounts suggest that the past two years have seen a rapid deterioration in public opinion on China around the world. Media reports and policy commentaries using data from international and national polls increasingly highlight this growing negativity toward China (Kassam 2021; Silver 2021; The Economist 2020). These accounts give the impression that until recently, China was seen as a benign, if not trusted, power. However, these are at odds with earlier narratives of China being poorly received, if not with outright hostility, in many parts of the developing world in the 2000s and early 2010s. As China's political and economic presence in developing countries rose rapidly, media reports of concerns over labor and environmental issues related to Chinese investment projects and the influx of Chinese workers, real or perceived, abounded. Signs of occasional tensions were very clear in Southeast Asia. In 2014, national protests and riots targeting Chinese businesses took place in the most dramatic fashion in Vietnam, where Chinese-owned factories were torched, and Chinese workers were attacked (Morris-Jung and Pham 2017). Myanmar's popular backlash against the China-backed Myitsone Dam project and the Letpadaung copper mine during the political transition of the early 2010s is well known and often cited as an example of the challenges that China faces in its overseas economic expansion (Chan 2017; Chan and Pun 2020). Examining such challenges is now a well-established part of the rapidly emerging "China in Southeast Asia" literature, as seen in recent publications by Diokno (2019), Hiebert (2020), Lampton, Ho, and Kuik (2020), Shambaugh (2020), and Strangio (2020).

Part of this dissonance may arise from the fact that most of the literature on public views on the rise of China in Southeast Asia has relied more on events such as protests and riots and less on public opinion data. Historical events and anecdotes, especially critical cases that can shape public opinion and government policy, are important evidence. Nevertheless, although public protests provide valuable information about how China is viewed in other countries, they need relatively high thresholds to be realized and are therefore rare. They also need to be filtered through many other factors, not least economic and political, to be observable, thus requiring a wide range of other considerations for analysis. As such, case-centric approaches are often not amenable to cross-national comparisons. In contrast, public opinion studies, especially in cross-national settings, can provide considerably larger-scale and comparable information. Public opinion research also enables more generalizable representations of the phenomenon. For Southeast Asia, although cross-country survey data, such as the Asian Barometer Survey (ABS), are 
available, analytical studies have been rare, with few exceptions, such as that of $\mathrm{Chu}$, Kang, and Huang (2015). Studies examining public views of a rising China in wider Asia, including both Northeast and Southeast Asian countries, have recently emerged (Sonoda 2021), yet they often include only two or three studies from Southeast Asia and thus offers limited coverage for intra-regional comparison.

In this study, I examine public opinion on China across Southeast Asian countries, particularly in the mid-2010s, just after Chinese foreign policy in the region underwent a major transformation under Xi Jinping. To study public perceptions of China in Southeast Asia, I specifically pursue two empirical questions: (1) how China fared in perceived influence and positivity compared to the U.S. at the national level and (2) what perception gaps existed in regional and national assessments of China's positive impact. To answer these questions, I used data from Wave 4 of the ABS, conducted in 2014-2016. The mid-2010s were critical times that witnessed a structural transformation in China's relations with the rest of the world. In the 2000s, elite assessments and public perceptions of China across the world were highly favorable. In East Asia, scholars were of the view that regional countries rarely felt threatened by China's rise (Kang 2007) and that even China agreed to be socialized into accepting preexisting norms of East Asian regional cooperation (Goh 2007). However, changes in China's foreign policy in the early 2010s with the ascent of Xi Jinping to power created a structural break with the earlier period. The first half of the last decade was also a period before the Trump administration in the U.S., China's heavy-handed "wolf-warrior diplomacy," and the COVID-19 pandemic, which brought about many complications in the geostrategic environment of Southeast Asia.

Examining Southeast Asian public perceptions of China matters because Southeast Asia is a region strategically important to the evolution of the U.S.China competition. Since the success of China's regional policy is critical to its global ambitions, examining the public views of China in its neighboring countries, especially in Southeast Asia, merits particular attention. If China cannot achieve regional leadership in Southeast Asia, it will be almost impossible for it to assume global leadership.

One might argue that public opinion comparisons across countries may raise questions regarding the validity of the findings due to the different regime types in Southeast Asia. Given the considerable heterogeneity of political systems and the various levels of political freedom, this is a valid point. However, regardless of regime type, public perceptions of a foreign power matter to a country's foreign relations. A democratic government is, in principle, more restricted by public opinion in terms of foreign policy. The case for an authoritarian government may 
be more complex. A nondemocratic or illiberal government often seeks to leverage or even manipulate anti-foreign sentiment to bolster its legitimacy and regime support. Thus, it is particularly vulnerable to nationalistic criticism when it appears unable to deliver on its nationalist promises (Zhao 2013). As such, nationalist, anti-China sentiment may place a constraint on the official policy of an authoritarian government in Southeast Asia and may restrain it from taking a blatantly pro-China stance to the extent that it is vulnerable to nationalistic criticism.

Examining cross-country patterns of public perceptions contributes to broader research into the alignment choices of Southeast Asian countries. There is considerable interest in how to classify Southeast Asian countries and locate them on a spectrum in terms of their accommodation of a rising China. In the recent literature on East Asian international relations, scholars have attempted to group Southeast Asian countries according to their foreign policy stances toward China (Chen and Yang 2013; Haacke 2019; Shambaugh 2020). Although there are slight disagreements over exactly where to locate these countries, it is generally agreed that while most countries are "hedging" or seeking to maintain a balance of influence from external powers, some countries are more aligned with China's strategic preferences than others. Cambodia is often classified as the most supportive of China's Southeast Asian policy, whereas Vietnam and the Philippines are considered the least aligned or even "soft-balancing" against China. This study introduces public opinion patterns to this debate and can offer a deeper understanding of the extent to which public preferences and official government orientations are aligned across regional states.

Before proceeding, it is necessary to define the scope of this study. The determinants of cross-country variations in public opinion on China are not addressed in this study. Since the key motivation of this study was to identify public opinion patterns across countries in light of the scarcity of previous studies, the question of what may be driving these variations is left unanswered and should be addressed in future research. Likewise, this study does not examine how public views of China measured by the ABS can be identified to influence individual countries' specific foreign policy. Whether and how successfully China has influenced public opinion in the regional states of Southeast Asia is also outside the scope of this study. China's soft power strategy and public diplomacy have become major research topics in the past decade, and there is a substantial body of literature on their evolution and performance (Cho and Jeong 2008; Lee and Hao 2018; Shambaugh 2013, 2015). Related to this literature, previous studies have also sought to understand the mediating effects of the domestic political conditions of China's soft power, although they have used 
data from outside the region (Hess and Aidoo 2014). I fully agree with the idea that deliberate strategies of domestic politicians in the face of political or electoral competition may significantly modify the way in which China's economic and diplomatic influence is channeled. This is also likely to have happened in Southeast Asia; however, it is also beyond the scope of this study.

This study proceeds as follows. The next section introduces key themes to be studied with respect to public perceptions of China, and more importantly, how those themes will be approached in this article. The following section presents analytical frameworks. The third section describes data and the metrics used. The fourth section presents findings. The final section concludes.

\section{EXAMINING PUBLIC OPINION ON CHINA IN SOUTHEAST ASIA}

Public perceptions of foreign powers, including China, can be usefully examined through the lens of the concepts of influence and positivity. The concept of influence, which denotes the public recognition of China's influence, is quite straightforward. China's influence primary comes from its economic might. China is an important partner in economic interactions due to its vast market size and growth potential. The stellar growth of the Chinese economy in the 2000s boosted Southeast Asian recovery from the 1997 Asian financial crisis and sustained the boom years, driven by a high Chinese demand for commodities and industrial inputs produced in the region (Coxhead 2007). This made China the top trade partner and a rising investor for most regional economies.

Accordingly, most of the international public recognizes the benefits of enhanced interactions with China. The sheer size of the Chinese market and dynamism make China an economic partner that neither firms nor the public can easily ignore. China is also a new and ambitious international investor that is more willing to take risks, thus providing new investment opportunities to countries that struggle to attract conventional investors. Chinese investment has also placed competitive pressure on existing investors, sometimes leading to better terms for host countries. The weight of economic imperative is well found in Canada, a country that reported a sharp increase in negativity toward China in the wake of recent commercial and diplomatic disputes. Li (2021) showed that despite a general decline in overall favorability, the Canadian public felt that expanding trade and investment links with China should be the top priority of the Canadian government's relations with it. ${ }^{1}$

1 Li (2021) provides a good up-to-date review of global opinion polls of public perceptions of China. 
The case of positivity, which refers to the evaluation of China's influence, is more complicated because it can be divided into two types according to its relationship with influence. The first type is positivity generated by influence in a way that "influence buys friends." In the economic domain, through close trade relations, foreign direct investment, and foreign aid, a country can receive positivity from the public. A previous study found that close economic ties appear to minimize low-intensity conflicts with China, although they do not necessarily reduce high-intensity conflicts (Zeng 2021). In the political domain, the public in some countries may see China as a champion of independence and a source of leverage against more powerful and threatening neighbors and isolation from the international community.

The other type is positivity undermined by influence in a way that "influence creates resentment." In the economic domain, the influx of Chinese goods, workers, and businesses may create steep competition for domestic manufacturers, workers, and traders. Economic dependence on China increases a country's vulnerability to manipulation and economic coercion. China, on its part, has made it clear that it is willing to use sanctions to "establish a reputation for resolve" to deter future challenges to its rise (Zhang 2019). The changes in China's geopolitical strategy under Xi Jinping (Smith 2021) have clearly aggravated the situation. In the political domain, China's support or patronage of unpopular governments or ruling elites may provoke a backlash. China has often been criticized as a patron of autocratic states (Bader 2015).

I make a distinction between positivity and favorability/approval, a related concept that is widely used in public opinion research. ${ }^{2}$ Favorability/approval metrics seek to capture respondents' overall affect regarding a subject and are usually obtained using a Likert scale or a feeling thermometer. An example is the question used by the Pew Research Center on the view of China. 3 Though informative, favorability is a concept separate from positivity, and it has clear

\footnotetext{
${ }^{2}$ Closely related to positivity toward China, but not discussed in this study is whether a China is seen as a model for development or governance. This is a conceptually separate issue. The soft power question whether the public admires or wants to emulate another country is indeed closely correlated with positive evaluations (Nye 2008). In fact, many in the developing world became curious whether China can be an alternative model of development for developing countries (Welsh and Chang 2015) and that was one important element of China's soft power that came to prominence in the late $2000 \mathrm{~s}$ (Cho and Jeong 2008). Nonetheless, for the purposes of this study, one must distinguish positivity toward China from the desire to emulate Chinese model of development. This is because people can see benefits from cooperation with China while not considering its mode of operation appropriate in their social and economic context, which may be different from China.

3 The question is "Please tell me if you have a very favorable, somewhat favorable, somewhat unf avorable or very unfavorable opinion of China" (https://www.pewresearch.org/global/database/indi cator/24/)
} 
limitations. Favorability is a vague concept and it rarely allows respondents to distinguish between the influence and positivity dimensions. It could be also problematic measures of affect fail to differentiate between aspects of the foreign relations in question (Li 2021). However, for countries that are under heavy Chinese economic influence, this differentiation can be important. The extent to which China is seen as influential and the extent to which its influence is viewed as positive should be examined separately.

Although current approaches to Southeast Asian perceptions of China can provide valuable information, they have two major limitations. First, they tend to rely on absolute assessments of China's influence or positivity in the region or a country. Survey results are usually, if not always, based on absolute metrics. For example, surveys report that a certain percentage of respondents believe that "China is the most influential power in Asia" or that "China does more good than harm" to the region or a country. Although these are a good starting point, I argue that they are insufficient on their own and should be combined with relative assessments of China's competitor-that is, the U.S. Conceptually, this is because perceptions of China, at both the elite and popular levels, are inherently strategic in nature, both in origins and implications. China's rise is a concept that implies the relative decline of the U.S. In the U.S.-China strategic competition, it is obvious that one is always viewed in relation to the other. If China is to become the next hegemon, it should offer something better than the current one or be seen as such. Thus, any conceptual analysis in this line of reasoning should reflect the competitive aspect. If China appears to have a positive margin over the U.S. in influence and positivity, its rise is much more consequential than currently recognized. In contrast, if China does not have that margin, the discourse on its rise should be qualified, even if the relative decline of the U.S. continues.

Moreover, in terms of measurement, some countries are inherently more inward-looking and nationalistic, thus underestimating the influence of any power. Although countries in Southeast Asia are generally suspicious of any sign of external intervention or manipulation due to their colonial experience, this proclivity may vary across countries. For these reasons, using an absolute measure without any comparison is susceptible to potentially misleading results. Comparisons offer more valid representations.

Furthermore, current approaches pay insufficient attention to perception gaps in countries' evaluations of China's impact on regional and domestic affairs. Identifying and placing countries' responses on a spectrum has been standard practice in the literature on Southeast Asia's alignment choices. Yet, gaps in perceptions between China being good to the region and China being good to one's own country have rarely been investigated. The distinction between 
regional and national assessments is critical because it has implications for understanding the regional response to China's rise. If perception gaps exist between an external power's impact on the region and its impact on a country, this predicts a divergence of interests. Furthermore, if these gaps vary significantly across countries, this implies varied levels of willingness to bear the costs of pursuing a solution through region-wide collective action. In other words, cross-country perception discrepancies between the extent of China's positive impact on the region and on an individual country may undermine efforts to create a coherent Southeast Asian policy on China, at least on the public opinion level.

Paying close attention to perception gaps driven by divergent national interests is not an extreme proposition when studying Southeast Asia. This region is characterized by geographic, historical, economic, political, and cultural heterogeneity and is undergoing a process of forging an unlikely "region" out of fragmentation and contradiction (Emmerson 1984). Its regional organization, the Association of Southeast Asian Nations (ASEAN), has been struggling to produce a coherent regional response to the changing strategic and economic environment in Southeast Asia. The lack of a coherent China strategy is attributed to the divergent, even conflicting, national interests of member states. This has forced the ASEAN to adopt the least ambitious measure, limiting the goal of its regional cooperation to mitigating the extent of the problem instead of working toward a solution (Davies 2018).

In dealing with China, the underlying diversity manifests itself as a divided Southeast Asia, lacking a coherent regional strategy and limited in bargaining power. More pertinent to this study, although South China Sea disputes constitute a regional security issue, threat perceptions differ dramatically between littoral states and non-littoral states. Cambodia even sees security benefits from its close alignment with China for balancing the influence of its more powerful neighbors, Thailand and Vietnam. China's economic domination over or coercion of a single country has cross-border and regional implications. However, the level of overdependence on China for trade, investment, and financial relations also varies, although China is a key economic partner with a large economic presence in all countries. Diverse conditions lead to divergent interests, which are likely to be reflected in country-level public opinion.

The above discussion suggests that a more accurate understanding of public opinion of China in the Southeast Asian context requires (1) relativity metrics to reflect the strategic nature of the U.S.-China competition, and (2) a way to gauge a discrepancy between regional and national assessments to reflect the collective action problem faced by divergent Southeast Asian countries. In the remaining 
of the study, I examine survey data through frameworks constructed to address these two specific limitations.

\section{ANALYTICAL FRAMEWORKS AND DATA}

I examine two questions: (1) how China fared in perceived influence and positivity compared to the U.S. at the national level and (2) what perception gaps existed in regional and national assessments of China's positive impact. For the first question, I construct a framework to map China's margin in influence and positivity compared to the U.S. The two dimensions "China's margin in influence compared to the U.S." and "China's margin in positivity compared to the U.S." combine to produce the following four outcomes (Table 1).

Table 1. Perceptions of China Compared to the U.S. at the National Level

\begin{tabular}{|c|c|c|c|}
\hline & \multicolumn{3}{|c|}{ China's Margin in Influence Compared to the U.S. } \\
\hline \multirow{3}{*}{$\begin{array}{c}\text { China's Margin } \\
\text { in Positivity } \\
\text { Compared to } \\
\text { the U.S. }\end{array}$} & & China Less Influential & China More Influential \\
\hline & $\begin{array}{l}\text { China More } \\
\text { Positive }\end{array}$ & $\begin{array}{l}\text { China is less influential but } \\
\text { its influence more positive }\end{array}$ & $\begin{array}{l}\text { China is more influential and } \\
\text { its influence more positive }\end{array}$ \\
\hline & $\begin{array}{c}\text { China More } \\
\text { Negative }\end{array}$ & $\begin{array}{l}\text { China is less influential and } \\
\text { its influence more negative }\end{array}$ & $\begin{array}{l}\text { China is more influential but } \\
\text { its influence more negative }\end{array}$ \\
\hline
\end{tabular}

Source: Author's construction

The results categorize countries into four groups. Countries in the first quadrant assign higher influence and positivity to China than the U.S. The same schematic applies to other quadrants, which will not be repeated, except for the fourth quadrant, which offers a contrast. This is the group of countries that assign greater influence but lower positivity to China compared to the U.S. These countries are in a position in which China's influence in the political, economic, or security domains may be relatively dominant but more poorly received compared to the influence of the U.S. Clustering countries in this way provides information and insights that can be compared to state-level alignment choices in Southeast Asia.

The second question requires a framework that compares regional- and national-level assessments of positivity toward China. The perception gap is conceptualized according to the difference between positivity toward the foreign power's impact on the region and positivity toward its impact on the respondents' country. This is again measured for China and the U.S. The second framework is presented in Table 2. 
Table 2. The Positivity Gap between Regional and National Assessments

\begin{tabular}{c|c|c}
\hline Perception Gap & $\begin{array}{c}\text { The extent to which the U.S. is } \\
\text { beneficial to the region is } \cdots \\
\text { the extent to which the U.S. is } \\
\text { beneficial to my country. }\end{array}$ & $\begin{array}{c}\text { The extent to which China is } \\
\text { beneficial to the region is } \cdots \\
\text { the extent to which China is } \\
\text { beneficial to my country. }\end{array}$ \\
\hline $\begin{array}{c}\text { Region benefitting more } \\
\text { than my country }\end{array}$ & Greater than & Greater than \\
\hline $\begin{array}{c}\text { No gap } \\
\text { more than region }\end{array}$ & Equal to & Equal to. \\
\hline
\end{tabular}

Source: Author's construction

For simplicity, I focus my discussion on outcomes related to China. The same logic applies to the assessments of the U.S. presented in the second column. Of the three possible outcomes related to China (presented in the third column), the second category-no gap-would be the least problematic. No gap suggests that China's regional positivity is equal to its national-level positivity. There is no conflict. The top right category is the outcome of respondents viewing the extent to which China benefits the region as greater than the extent to which it benefits their own countries. This may imply a view that the country is lagging behind in its beneficial relationship with China relative to other regional countries. Such public opinion may support a foreign policy that promotes closer ties with China.

In contrast, the bottom right category is the outcome where the extent to which China's influence benefits a country is greater than the extent to which it benefits the region. This is the opposite of the top right category. This may lead to less public support for regional cooperation with neighboring countries due to a misalignment of incentives between regional and national interests. If most regional countries or key countries in regional diplomacy have such tendencies, this is likely to undermine the development of a coherent regional response to China's rise.

For the analysis, I used data from Wave 4 of the ABS, which is a cross-national public opinion data series. The dataset used for the present analysis includes responses from 10,216 respondents interviewed between 2014 and 2016 in eight Southeast Asian countries. ${ }^{4}$ Besides the fact that the ABS has a standard battery of questions that measure public views of a foreign country, it encompasses most of Southeast Asia, with eight regional countries, excluding Brunei and Laos. 5 The

4 Table A1 shows the year of fieldwork and the sample sizes for each country. 
geographic coverage is one of the key strengths of the ABS. A few words are in order to discuss the validity of examining only data from Wave 4. Mid-2010s, covered by Wave 4, were the early years of the current phase of the China's assertive diplomacy. As Chu, Kang, and Huang (2015) correctly pointed out in their ABS Wave 3 analysis, the first half of the 2010s witnesses a series of events that dramatically changed the China's approach to Southeast Asia. Xi Jinping became China's president in 2012 and launched the Belt and Road Initiative (BRI) in 2013, ending China's decades-long foreign policy of "hide your strength and bide your time." The ambitious economic promises made by the BRI may have drawn some countries closer to China while the increasingly heavy-handed Chinese diplomacy may have alienated others amid increasing Chinese economic presence.

I created four outcome variables using responses to six survey questions from Wave 4: influence, positivity, U.S. gap, and China gap. The influence variable reports the margin that China has over the U.S. in the "the country has influence on my country" category. China's margin over the U.S. in perceived influence on the respondents' own countries is calculated by taking the difference between two intermediate variables, each of which is the national share of positive responses to the following question: "How much influence does China/the U.S. have on your country?" The positivity variable is the key variable of interest and takes the difference between the shares of "China's influence on my country is more positive than negative" and "The U.S.'s influence on my country is more positive than negative" by country. Finally, the US/China gap variable takes the difference between the shares of "The U.S./China does more good than harm to the region" and "The U.S.'s/China's influence on my country is positive." Because they take the difference between the response percentages, they are presented on a percentage point scale. Detailed information on the methodology is provided in Table A2 in the Appendix.

\section{CHINA'S MARGIN OVER THE U.S. IN INFLUENCE AND POSITIVITY}

First, I discuss the means and variations of influence and positivity. Table 3 presents the values for each country, along with their means and standard deviations. Influence and positivity show quite different tendencies. The mean of influence is positive, suggesting that China is considered, on average, more

5 There are surveys that poll all Southeast Asian countries, such as the ISEAS-Yusof Ishak Institute's State of Southeast Asia Survey Report, yet it examines the view of policy elites (ISEAS-Yusof Ishak Institute 2021). 
influential than the U.S. in Southeast Asia. In fact, in all countries except the Philippines, the share of the responses that China is influential in the respondents' countries is higher than that for the U.S., with the gap in Myanmar reaching 26.2 percentage points. ${ }^{6}$ However, the mean of positivity for China is negative, suggesting that it lags behind the U.S. in perceived positivity. China's influence is considered more beneficial only in Malaysia, Indonesia, and Thailand. The standard deviation of positivityis considerably larger than that of influence. This indicates a wider divergence between Southeast Asian countries in their assessments of the positivity of China's influence than in their assessments of the magnitude of its influence. These findings are consistent with the broader narrative about Southeast Asia that (1) China is considered a more important power than the U.S., but public attitudes toward it are not positive in many parts of the region, and (2) regional countries have heterogeneous interests and attitudes regarding China's rise.

Table 3. China's Margin over the U.S. in Public Perceptions by Country

\begin{tabular}{lcc}
\hline \multicolumn{1}{c}{ Country } & $\begin{array}{c}\text { Influence on the Respondents' Own } \\
\text { Countries }\end{array}$ & $\begin{array}{c}\text { Positivity (Positive Influence) on the } \\
\text { Respondents' Own Countries }\end{array}$ \\
\hline Malaysia & 4.1 & 18.0 \\
Indonesia & 1.3 & 12.8 \\
Thailand & 2.0 & 6.4 \\
Singapore & 3.4 & -7.4 \\
Cambodia & 12.6 & -8.6 \\
Mean & 5.5 & -11.3 \\
Myanmar & 26.2 & -20.4 \\
Philippines & -14.3 & -30.1 \\
Vietnam & 8.7 & -60.9 \\
\hline Std. deviation & 11.4 & 25.8 \\
Min & -14.3 & -60.9 \\
Max & 26.2 & 18.0 \\
\hline
\end{tabular}

Note: Measured by percentage point, not by percent. Countries are sorted by positivity.

Source: Author's calculation using data from the ABS Wave 4.

\footnotetext{
6 It is interesting to note that such patterns of public attitudes that the Philippines is an outlier correspond with elite survey results when measures are taken in the political and security domain separately from the economic domain. In State of Southeast Asia Survey Report 2021, the Philippines is the only Southeast Asian country where the number of respondents who chose the U.S, as the most influential political and strategic power in the region outnumbered those who chose China (ISEASYusof Ishak Institute 2021). Nonetheless, China was chosen as the most influential economic power by respondents from all Southeast Asian countries in the same survey.
} 
Moving to the distribution of countries according to influence and positivity, three groups are identified (Figure 1). The first group occupies the first quadrant, in which China is seen as more influential than the U.S., and its influence is viewed as more beneficial than that of the U.S. for the respondents' own countries. Malaysia, Indonesia, and Thailand belong to this group. The second quadrant, in which China is seen as less influential than the U.S., but its influence is viewed as more beneficial than that of the U.S., is empty. This probably suggests that China is perceived by many in the region as a dominant economic and political force. The second group, which in fact includes only the Philippines, is found in the third quadrant. The Filipino public sees China as less influential than the U.S. and considers its influence less beneficial than that of the U.S. In the first and second groups, there is consistency between or alignment across Influence and positivity. This is not the case for the third and most interesting group, located in the fourth quadrant. Here, according to public perceptions, China is more influential than the U.S., but its influence is less beneficial than that of the U.S. Singapore, Cambodia, Myanmar, and Vietnam belong to this group. These countries are thus characterized by a contradiction between influence and positivity. Two findings regarding this group are worth further discussion. First, Cambodia's position suggests that, despite its reputation as the most closely aligned with China in the region, public attitudes toward China suggest otherwise. Second, the fact that the Philippines and Vietnam belong to distinct groups is interesting, as it deviates from the common notion that both of these countries are at the forefront of Southeast Asian conflicts with China.

I now discuss two countries that represent the first and fourth quadrants. ${ }^{7}$ Perceptions of China's influence are aligned in the first quadrant and conflict in the fourth quadrant. Indonesia constitutes the first group along with Malaysia and Thailand where the publics assess China more highly both in terms of influence and positivity at the country level. Although China's margin over the U.S. is moderate, China clearly has a surplus in both indicators. Indonesia may represent a Southeast Asian position where Chinese security threats are limited and potential economic benefits with close ties with China are substantial. Unlike Vietnam and the Philippines, Indonesia does not have a territorial dispute with China in the South China Sea. Its government officially has been staying out of the dispute maintaining that Indonesia is not a party to the territorial dispute in the South China Sea (Sirega 2020).

7 The Philippines is discussed in the next section. 
Figure 1. China's Margin over the U.S. in Influence and Positive Impact on the Respondents' Own Countries

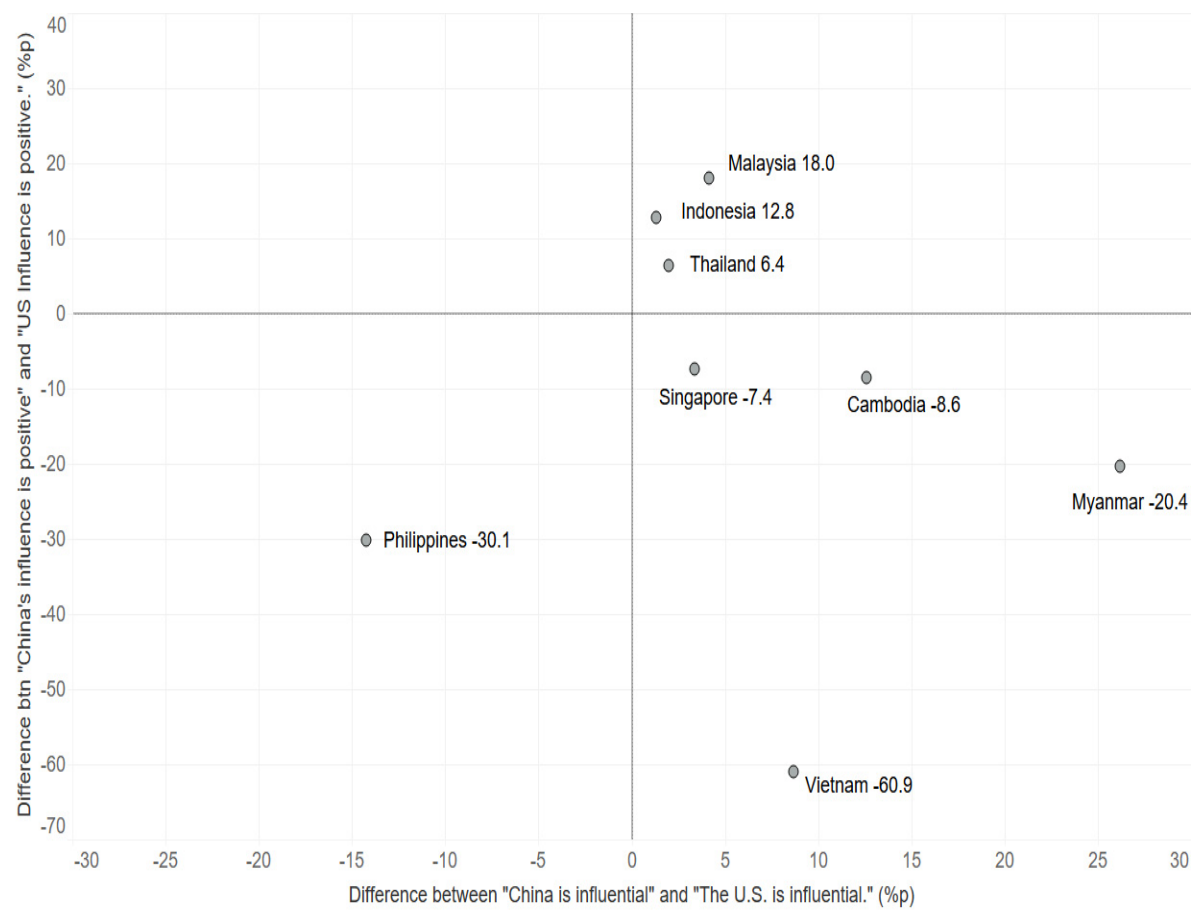

Note: Numbers next to a country name indicates the positivity gap toward China and the U.S. Source: ABS Wave 4 (2014-2016)

On the economic front, China's massive demand global commodities fueled Indonesia's economic expansion for much of the 2000s and onward and made China as the country's top export market (Shrestha and Coxhead 2018). Although Indonesia maintained a limited role as an investor earlier, China's investment came to prominence in Indonesia with the launch of the Belt and Road Initiative (BRI) in 2013. President Jokowi's national agenda of massive infrastructure development fitted well with the BRI and this gave a high-profile status to China as an investor despite domestic concerns and criticism around Chinese projects (Anwar 2019).

Yet one should note that China's surplus in visibility and positivity in this regard is quite modest, probably reflecting Indonesia's wariness toward China's intentions. Large-scale infrastructure projects may have created anxiety about increasing Chinese presence to balance out any enthusiasm for close ties with 
China (Herlijanto 2017). Even on the security front, China's claims to historical fishing rights in the exclusive economic zone (EEZ) off the coast of Indonesia's Natuna Island have created concerns in Indonesia. The intrusion of Chinese fishing vessels and their illegal fishing in the Natuna Island waters emerged as a national issue in Indonesia in 2015 (Meyer et al. 2019). The Indonesian government cracked down on Chinese illegal fishing and there were confrontations between Coastguards from two countries. Nonetheless, it did not lead to anti-China sentiment. An Indonesia national survey conducted in 2017, a year later than the ABS Wave 4's Indonesia survey, report that 41 percent of the respondents think China will have a positive impact on Indonesia whereas 39 percent think the impact will be negative (Fossati, Hui and Negara 2017). The same survey also reports that the majority of the public thinks close economic relations with China will benefit China although the its extent varies. Such popular sentiment is not incongruous with elite views. Yeremia (2020) interviews Indonesia policy and academic elites to find that China is perceived as a threat rather than an opportunity in Indonesia but the concerns were over China's economic exploitation and political subordination rather than military aggression.

Vietnam represent the cluster of "conflicted" countries. The extent to which its public sees China influential in its country is greater than the extent of the U.S. being influential, yet the degree of positive evaluation of China's influential is much lower than the degree for the U.S. influence. China's deficit in positivity in Vietnam is as large as 69.9 percentage point, suggesting deep contradictions felt by the Vietnamese public. Vietnam has a long historical relationship with China over two thousand years and past wars and conquests work as a source of Vietnam's strong nationalist sentiments toward its northern neighbor (Womack 2006). Since 2010, China has become a critical trade partner of Vietnam. The rise of its export-manufacturing industry, particularly the electronics sector, has been aided by Vietnam's integration into China-centered regional production network where parts and components, as well as industrial machineries, are imported by multinational companies from China for assembly and processing for export. It transformed the structure of the Vietnamese industry and export in the past decade, putting Vietnam on a high growth path. Yet close economic ties with China appears to raise concerns of over-dependence on China rather than appreciate more economic opportunities (Ngan Ahn 2014)

Most notably, Vietnam contests China's claim to the South China Sea. The dispute clearly affects public attitudes toward China and can serve as a trigger for mass mobilization. An unprecedented public display of anti-China sentiment took place during the 2014 protests, whem China's state-owned oil company 
placed an oil rig to contested waters near the Paracel Islands in the South China Sea. This triggered nation-wide anti-China protests and riots during which time Chinese workers were attacked and Chinese-owned factories were set on fire (BBC News 2014). Thousands of Chinese citizens were evacuated from Vietnam and China later withdrew the rig.

At the same time, Vietnam is the country where the government may have a political incentive to carefully manage and reign in negative public attitudes to China. To be sure, no government in Southeast Asia is willing to confront China heads-on or appear to join any explicit international containment campaign against China. Yet Vietnamese elite attitudes toward China may be more conflicted than the public perceptions because the Communist Part of Vietnam has an ideological reason to cooperate with other powerful Communist regimes (Do 2018). Combined, this may be why Vietnam's official policy is much more measured than public preferences (Le 2016).

\section{GAPS BETWEEN REGIONAL AND NATIONAL ASSESSMENTS}

Now I examine the potential discrepancy in regional and national assessments of China's positivity across countries. The values of the Gap variables are presented along with its summary statistics in Table 4 and again visually in Figure 2.

For comparison purposes, I first discuss the results concerning the U.S. Respondents in all countries except Malaysia and the Philippines report that the extent to which the U.S.'s influence benefits the region is greater than the extent to which it benefits their own countries. Except for the Philippines, in which the value is close to zero, the responses in the other seven countries suggest that their countries may be failing to take advantage of the opportunities created by the U.S.'s presence in the region. This is an interesting finding.

Moving to the results concerning China, the finding that respondents in all eight countries assess its regional impact more negatively than its impact on their own countries is also interesting. It suggests that the Southeast Asian public sees China's influence as less beneficial when the reference is the region than when it is one's own country. The Philippines, Singapore, and Indonesia show two-digit gaps, while Vietnam and Myanmar exhibit small gaps. This may suggest that the Southeast Asian public may be more optimistic about the impact of China's rise on one's own country and more pessimistic about its impact on the region. This could create a moral hazard problem with Southeast Asia's collective response to China's rise from a public opinion point of view. 
Table 4. Discrepancy in Positivity between the Regional and National Levels for the U.S. and China

\begin{tabular}{lcc}
\hline \multicolumn{1}{c}{ Country } & $\begin{array}{c}\text { The difference between the U.S. good to } \\
\text { the region and good to my country }\end{array}$ & $\begin{array}{c}\text { The difference between China good to the } \\
\text { region and good to my country }\end{array}$ \\
\hline Myanmar & 45.7 & -2.3 \\
Vietnam & 7.6 & -5.4 \\
Thailand & 14.8 & -6.5 \\
Cambodia & 8.8 & -7.2 \\
Malaysia & -10.0 & -9.3 \\
Indonesia & 8.7 & -10.1 \\
Singapore & 0.7 & -10.5 \\
Philippines & -1.0 & -22.4 \\
\hline Mean & 9.4 & -9.2 \\
Std. deviation & 16.5 & 6.0 \\
Min & -10.0 & -22.4 \\
Max & 45.7 & -2.3 \\
\hline
\end{tabular}

Note: Measured by percentage point, not by percent. Countries are sorted by the difference for China (third column). Source: Author's calculation using data from the ABS Wave 4.

Another interesting finding is that countries that are usually grouped together are in fact located at greater distances from each other. Popular media, policy documents, and academic studies frequently group the Philippines and Vietnam together as the "least aligned with China" in the region due to South China Sea territorial disputes. Nonetheless, the patterns emerging from this analysis clearly show that the two countries are distinctly different. The Philippines is characterized by the widest perception gap between the region and country levels, with the discrepancy standing at 22.4 percentage point. This is more than double the level of second-placed Singapore. The Filipino public sees China's impact on its own country considerably more positively than its impact on the region. An explanation for this could be that regional assessments involve more long-term considerations, while country-level assessments are driven more by narrowly defined national interests. 
Figure 2. Discrepancy in Positivity between the Regional and National Levels for the U.S. and China

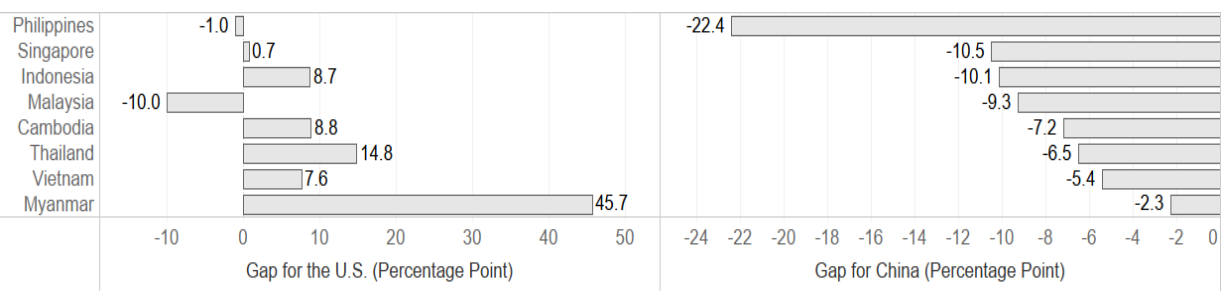

Note: Measured by percentage point, not by percent.

Source: Author's calculation using data from the ABS Wave 4.

I now examine two countries worth further discussion due to their roles in regional cooperation for a collective response to the US-China competition. Cambodia is often described as a close ally of China or a country aligned with China's regional strategic preferences (Ciorciari 2015). When explaining Cambodia's alignment choice, most academic analyses and popular accounts emphasize political and security factors. It is suggested that the absence of territorial or security disputes with China, China's support of Cambodia against pressure from Vietnam-the source of its primary security challenge-and its increasing international isolation due to Hun Sen's authoritarian rule contribute to Cambodia's gravitation to Beijing. The Wave 4 ABS data suggest that, in absolute terms, the Cambodian public's assessment of China's influence on the country is substantially positive, with 67.2 percent positive responses. However, in comparison to the positivity levels that the U.S. enjoys, China has a deficit of 8.6 percentage points (Table 2). Although the deficit is not overwhelming, it suggests that Cambodia's public is more negative toward China than its government is. A 2014 report found that a broad anti-China sentiment was largely absent from Cambodia despite strikes in Chinese-owned factories and community protests against displacement caused by China-funded infrastructure development (Nyíri 2014). This was before a substantial increase in public resentment over China's economic domination over Cambodia's major province of Sihanoukville, home to its only deep-sea port and a major tourist destination, and the influx of Chinese migrants there as a result of massive investment in casinos and real estate development (Wright 2018). It would be interesting to see whether public opinion on China has changed since the mid-2010s.

Finally, the Philippines is a peculiar case. It is the only military ally of the U.S. in Southeast Asia and has close political and historical ties with it. At the same time, it is in dispute with China, along with other regional states, over the Scarborough Shoal and parts of the Spratly Islands. For this reason, the 
Philippines, along with Vietnam, is often considered to be at the forefront of security disputes with China in the region. Therefore, the higher positivity toward the U.S. than China in the Philippines is not surprising. As shown in Figure 1, the Filipino public's perceptions according to the Wave 4 ABS fit the common narrative that the country traditionally sees its relationship with the U.S. as much closer and more positive than its relationship with China. The developments in the South China Sea dispute in the early 2010s may have contributed to widening the U.S.'s margin over China. After the diplomatic standoff between China and the Philippines over the Scarborough Shoal in April 2012, the government of the Philippines brought a case against China to the Permanent Court of Arbitration (PCA) under the United Nations Convention on the Law of the Sea (UNCLOS). In the meantime, China unofficially imposed economic sanctions on the Philippines by suspending fruit imports and outbound tourism (Lai 2018). Thus far, this is consistent with the findings (reported in the preceding section) that the Philippines is the only country in which China suffers deficits in both Influence and Positivity compared to the U.S., as shown in Figure 1.

However, the gap analysis results reveal something different. Two findings stand out. First, the region-wide finding that the extent to which China's influence is seen as beneficial for the respondents' own countries is greater than the extent to which it is thought to benefit the region is also observed in the Philippines. As previously discussed, the fact that negative gaps are observed in all regional states suggests that Southeast Asia as a whole may have a collective action problem since each country has a different incentive to manage the Chinese challenge. The second finding, obtained from the distribution of country values, is that the size of the negative gap is largest in the Philippines, a country considered to be at the forefront of regional tensions with China. It should be noted that the survey was conducted in 2014, during the presidency of Benigno Aquino III, before the major disruption to the country's foreign policy on China under President Rodrigo Duterte. Although his China policy has been often inconsistent, President Duterte for the most part ignored the 2016 PCA ruling rejecting China's claims of historical rights to the South China Sea and took a softer and more accommodating approach to China's aggressive activities there.

Understanding why, despite the strongly negative assessment of China's influence, the divergence in positivity between the region and the country is greatest in the Philippines requires a separate investigation. However, it is clear that the Philippines and Vietnam, two countries that are often grouped together in the spectrum of alignment choices, are markedly different in their perception gaps. In contrast to the Philippines, Vietnam has one of the smallest gaps of all countries. Although it also reports greater national than regional positivity 
toward China, it has a relatively small gap of 5.4 percentage points.

\section{CONCLUSION}

Understanding Southeast Asian public opinion on China can contribute to improving our knowledge of alignment choices faced by Southeast Asia. To provide analytical leverage, this study applied new metrics to better identify China's place in the mind of Southeast Asian publics. The findings indicate that public perceptions by country are not radically different from commonly known government-level orientations toward China. Yet there are interesting patterns of clusters across countries and gaps in perceptions. First, countries are clustered in the extent to which is China is positioned in relation to the U.S. in influence and positivity. Respondents in Malaysia, Indonesia, and Thailand consistently regard China more influential and more beneficial than the U.S. while others, including Singapore, Cambodia, Myanmar and Vietnam, face a contradiction between China being more influential but less beneficial than the U.S.

Second, in all countries, Southeast Asian respondents think that the extent to which China benefits their own country is greater than the extent to which China benefits the region, implying a potential collective action problem for a regional response. It is also interesting the largest perception gap is reported in the Philippines, the country at the forefront of the South China Sea disputes with China in the mid-2010s.

Cross-country variations in public opinion on China has influence on the government's foreign policy. The two are more aligned in some countries and diverge in others. An accommodative policy toward China would have been largely unproblematic in Malaysia, Indonesia, and Thailand from a public opinion perspective whereas it would have been inconsistent with popular sentiment in other countries, including Cambodia and Myanmar and not to mention Vietnam and the Philippines. Yet at the same time, the peoples of Southeast Asian regional states clearly had different interests in bearing the cost of addressing the China question as seen in the perception gaps between regional and national assessments of China's positivity. The findings reaffirm the challenge of creating and sustaining a coherent and effective regional response in Southeast Asia to the rise of China. It is not only the policy elites but the masses that have divergent views and interests across countries.

Finally, one would wonder what may explain the patterns of clusters and gaps found in this study. Economic and political relations, likely conditioned by historical factors, may play an important role in shaping public opinion on China. In fact, the extent to which historical experiences of interactions with China may 
determine or shape public attitudes can be critical. Although China is an intricate part of the region's history, the weight of history can be heavier for some than others. Understanding the extent to which different Southeast Asian countries respond to contemporary events or deep-seated historical issues require country-level public opinion data measured over time, which can be taken up by future research. 


\section{REFERENCES}

Anwar, Dewi Fortuna. 2019. "Indonesia-China Relations: Coming Full Circle?" Southeast Asian Affairs, ISEAS -Yusof Ishak Institute, 145-162.

Bader, Julia. 2015. "China, Autocratic Patron? An Empirical Investigation of China as a Factor in Autocratic Survival." International Studies Quarterly, 59(1), 23-33.

BBC. 2014. "Vietnam Anti-China Protest: Factories Burnt" BBC News (May 14). Accessed at https://www.bbc.com/news/world-asia-27403851 (September 1, 2021).

Booth, Anne. 2020. "ASEAN-China Trade and Investment: Diversity versus Dependence" In Donald K. Emmerson ed., The Deer and the Dragon: Southeast Asia and China in the 21st Century, Shorenstein Asia-Pacific Research Center/ ISEAS-Yusof Ishak Institute. 65-87.

Chan, Debby Sze Wan. 2017. "Asymmetric Bargaining between Myanmar and China in the Myitsone Dam Controversy: Social Opposition akin to David's Stone against Goliath.” The Pacific Review 30(5), 674-691.

Chan, Debby Sze Wan, and Ngai Pun. 2020. "Renegotiating Belt and Road Cooperation: Social Resistance in a Sino-Myanmar Copper Mine." Third World Quarterly 41(12), 2109-2129.

Chen, Ian Tsung-Yen, and Alan Hao Yang. 2013. "A Harmonized Southeast Asia?

Explanatory Typologies of ASEAN Countries' Strategies to the Rise of China." The Pacific Review 26(3), 265-288.

Cho, Young Nam, and Jong Ho Jeong. 2008. "China's Soft Power: Discussions, Resources, and Prospects." Asian Survey 48(3), 453-472.

Chu, Yun-han, Liu Kang, and Min-hua Huang. 2015. "How East Asians View the Rise of China." Journal of Contemporary China 24(93), 398-420.

$\mathrm{Chu}$, Yun-han and Yu-tzung Chang. 2017. "Xi's Foreign-Policy Turn and Asian Perceptions of a Rising China." Global Asia. 12(1), 104-111.

Ciorciari, John D. 2015. "A Chinese Model for Patron-client Relations? The SinoCambodian Partnership." International Relations of the Asia-Pacific 15 (2), 245-278.

Coxhead, Ian. 2007. "A New Resource Curse? Impacts of China's Boom on Comparative Advantage and Resource Dependence in Southeast Asia." World Development 35 (7), 1099-1119.

Davies, Mathew. 2018. Ritual and Region: The Invention of ASEAN. Cambridge University Press.

Diokno, Maria Serena I., Hsin-Huang Michael Hsiao and Alan H. Yang. eds. 2018. China's Footprints in Southeast Asia. National University of Singapore 
Press.

Do, Thanh Hai. 2018. "Vietnam: Riding the Chinese Tide." The Pacific Review. 31(2), 205-220.

Emmerson, Donald K. 1984. "'Southeast Asia': What's in a Name?” Journal of Southeast Asian Studies 15(1), 1-21.

Fossati, Diego and Yew-Foong Hui and Siwage Dharma Negara. 2017. "The Indonesia National Survey Project: Economy, Society and Politics.” Trends in Southeast Asia Series. Singapore: ISEAS Publishing.

Friedrichs, Jörg. 2019. "Explaining China's Popularity in the Middle East and Africa.” Third World Quarterly 40(9), 1634-1654.

Goh, Evelyn. 2007. "Great powers and Hierarchical Order in Southeast Asia: Analyzing Regional Security Strategies.” International Security 32(3), 113-157.

Haacke, Jürgen. 2019. "The Concept of Hedging and Its Application to Southeast Asia: A Critique and a Proposal for a Modified Conceptual and Methodological Framework." International Relations of the Asia-Pacific 19(3), 375-417.

Herlijanto, Johannes. 2017. "Public Perceptions of China in Indonesia: The Indonesia National Survey." ISEAS Perspective 2017(89).

Hess, Steve, and Richard Aidoo. 2014. "Charting the Roots of Anti-Chinese Populism in Africa: A Comparison of Zambia and Ghana.” Journal of Asian and African Studies 49 (2), 129-147.

Hiebert, Murray. 2020. Under Beijing's Shadow: Southeast Asia's China Challenge. Center for Strategic \& International Studies.

Kang, David. C. 2007. China Rising: Peace, Power, and Order in East Asia. Columbia University Press.

Kassam, Natasha. 2021. Lowy Institute Poll, 23 June 2021. Accessed at https://poll. lowyinstitute.org/report/2021/ (September 1, 2021).

Lai, Christina Lai. 2018. "Acting one way and talking another: China's coercive economic diplomacy in East Asia and beyond." The Pacific Review, 31(2), 169-187.

Lampton, David M., Selina Ho, and Cheng-Chwee Kuik. 2020. Rivers of iron: Railroads and Chinese power in Southeast Asia. University of California Press.

Le, Hong Hiep. 2016. Living Next to the Giant: The Political Economy of Vietnam's Relations with China under Doi Moi. ISEAS Publishing.

Lee, Min-gyu, and Yufan Hao. 2018 "China's Unsuccessful Charm Offensive: How South Koreans Have Viewed the Rise of China over the Past Decade." Journal of Contemporary China 27(114), 867-886. 
Li, Xiaojun. 2021. "More than Meets the Eye: Understanding Perceptions of China Beyond the Favorable-Unfavorable Dichotomy." Studies in Comparative International Development 56(1), 68-86.

Meyer, Patrik Kristhope, Achmad Nurmandi, and Agustiyara Agustiyara. 2019. "Indonesia's swift securitization of the Natuna Islands how Jakarta countered China's claims in the South China Sea." Asian Journal of Political Science 27(1), 70-87.

Morris-Jung, Jason, and Pham Van Min. 2017. "Anti-Chinese Protest in Vietnam: Complex Conjunctures of Resource Governance, Geopolitics and StateSociety Deadlock." Chapter. In In China's Backyard: Policies and Politics of Chinese Resource Investments in Southeast Asia, edited by Jason Morris-Jung, 229-55. ISEAS-Yusof Ishak Institute.

Ngan Anh. 2014. "Vietnam has Trouble Escaping Dependence on China through FTAs". Thanh Nien News (July 15). Accessed at https://www.bilaterals.org /?vietnam-has-trouble-escaping\&lang=en (September 1, 2021).

Nye, Joseph S. 2004. Soft Power: The Means to Success in World Politics. New York: Public Affairs.

Nyíri, Pál. 2014. "New Chinese Migration and Capital in Cambodia." Trends in Southeast Asia. Singapore: ISEAS Publishing.

Shambaugh, David. 2013. China Goes Global: The Partial Power. Oxford: Oxford University Press.

. 2015. "China's Soft-power Push: The Search for Respect." Foreign Affairs 94(4), 99-107.

. 2020. Where Great Powers Meet: America and China in Southeast Asia. Oxford University Press.

Shrestha, Rashesh and Ian Coxhead. 2018. "Can Indonesia Secure a Development Dividend from Its Resource Export Boom?" Bulletin of Indonesian Economic Studies 54(1), 1-24.

Silver, Laura. 2021. "China's international image remains broadly negative as views of the U.S. rebound." Pew Research Center (June 30). Accessed at https://www.pewresearch.org/fact-tank/2021/06/30/chinas-internationalimage-remains-broadly-negative-as-views-of-the-u-s-rebound/ (September 1, 2021).

Sirega, Kiki. 2020. "Why Indonesia is reaffirming its position on the South China Sea and turning down China's offer for bilateral talks" CNA. (June 19). Accessed at https://www.channelnewsasia.com/asia/indonesia-china-so uth-china-sea-united-nations-653521 (September 1, 2021).

Smith, Stephen N. 2021. "Harmonizing the Periphery: China's Neighborhood Strategy under Xi Jinping." The Pacific Review 34(1), 56-84. 
Sonoda, Shigeto. 2021. "Asian Views of China in the Age of China's Rise: Interpreting the Results of Pew Survey and Asian Student Survey in Chronological and Comparative Perspectives, 2002-2019." Journal of Contemporary East Asia Studies, 1-18.

Strangio, Sebastian. 2020. In the Dragon's Shadow: Southeast Asia in the Chinese Century. Yale University Press.

The Economist. 2020. Americans Take an Ever More Negative View of China. The Economist(April 21). Accessed at https://www.economist.com/graphicdetail/2020/04/21/americans-take-an-ever-more-negative-view-of-china (September 1, 2021).

Welsh, Bridget and Alex Chang. 2015. Choosing China: public perceptions of 'China as a model', Journal of Contemporary China, 24(93), 442-456.

Womack, Brantly. 2006. China and Vietnam. New York: Cambridge University Press.

Wright, George. 2018. "Anti-Chinese Sentiment on the Rise in Cambodia" The Di plomat. (November 7). Accessed at https://thediplomat.com/2018/11/anti -chinese-sentiment-on-the-rise-in-cambodia/ (September 1, 2021).

Yeremia, Ardhitya Eduard. 2020. "Indonesian Diplomats' and Foreign Policy Scholars' Perceptions and Their Implications on Indonesian Foreign Ministry Bureaucratic Responses to a Rising China.” The Pacific Review, $1-27$.

Zhang, Ketain. 2019. "Cautious Bully: Reputation, Resolve, and Beijing's Use of Coercion in the South China Sea." International Security 44(1), 117-159.

Zhao, Suisheng. 2013. "Foreign Policy Implications of Chinese Nationalism Revisited: The Strident Turn." Journal of Contemporary China 22(82), 535 $-53$.

Zeng, Yuleng. 2021. "Does Money Buy Friends? Evidence from China's Belt and Road Initiative." Journal of East Asian Studies 21(1), 75-95.

[Received Sep 26, 2021; Revised Nov 22, 2021; Accepted Nov 22, 2021] 


\section{APPENDIX}

Table A1. Data Profile

\begin{tabular}{l|c|c}
\hline \multicolumn{1}{c|}{ Country } & Year of Survey Fieldwork & N \\
\hline Malaysia & 2014 & 1,207 \\
\hline Philippines & 2014 & 1,200 \\
\hline Singapore & 2014 & 1,039 \\
\hline Thailand & 2014 & 1,200 \\
\hline Cambodia & 2015 & 1,200 \\
\hline Myanmar & 2015 & 1,620 \\
\hline Vietnam & 2015 & 1,200 \\
\hline Indonesia & 2016 & 1,550 \\
\hline Total & & 10,216 \\
\hline
\end{tabular}

Source: The ABS

Table A2. Variables

\begin{tabular}{|c|c|c|c|c|}
\hline $\begin{array}{l}\text { Outcome } \\
\text { Variable }\end{array}$ & $\begin{array}{l}\text { Intermediate } \\
\text { Variables (IV) } \\
\end{array}$ & $\begin{array}{c}\mathrm{Q} \\
\text { Number }\end{array}$ & Questions & Response Categories \\
\hline \multirow{2}{*}{$\begin{array}{l}\text { China's } \\
\text { Margin in } \\
\text { Influence }\end{array}$} & IV 1 & 168 & $\begin{array}{l}\text { How much influence } \\
\text { does China have on our } \\
\text { country? }\end{array}$ & $\begin{array}{l}\text { “-1 'Missing' } \\
1 \text { 'A great deal of influence' } \\
2 \text { 'Some influence' } \\
3 \text { 'Not much influence' } \\
4 \text { 'No influence at all' } \\
7 \text { 'Do not understand the question' } \\
8 \text { 'Can't choose' } \\
9 \text { 'Decline to answer'” }\end{array}$ \\
\hline & IV 2 & 170 & $\begin{array}{l}\text { How much influence } \\
\text { does the United States } \\
\text { have on our country? }\end{array}$ & $\begin{array}{l}\text { “-1 'Missing' } \\
1 \text { 'A great deal of influence' } \\
2 \text { 'Some influence' } \\
3 \text { 'Not much influence' } \\
4 \text { 'No influence at all' } \\
7 \text { 'Do not understand the question' } \\
8 \text { 'Can't choose' } \\
9 \text { 'Decline to answer'” }\end{array}$ \\
\hline $\begin{array}{l}\text { China's } \\
\text { Margin in } \\
\text { Positivity }\end{array}$ & IV 3 & 169 & $\begin{array}{l}\text { General speaking, the } \\
\text { influence China has on } \\
\text { our country is? }\end{array}$ & \begin{tabular}{|l} 
“-1 'Missing' \\
1 'Very positive' \\
2 'Positive' \\
3 'Somewhat positive' \\
4 'Somewhat negative' \\
5 'Negative' \\
6 'Very negative' \\
7 'Do not understand the question' \\
9 'Decline to answer' "
\end{tabular} \\
\hline
\end{tabular}




\begin{tabular}{|c|c|c|c|c|}
\hline $\begin{array}{l}\text { Outcome } \\
\text { Variable }\end{array}$ & $\begin{array}{l}\text { Intermediate } \\
\text { Variables (IV) }\end{array}$ & $\begin{array}{c}\mathrm{Q} \\
\text { Number }\end{array}$ & Questions & Response Categories \\
\hline & IV 4 & 171 & $\begin{array}{l}\text { General speaking, the } \\
\text { influence the United } \\
\text { States has on our } \\
\text { country is? }\end{array}$ & $\begin{array}{l}-1 \text { 'Missing' } \\
1 \text { 'Very positive' } \\
2 \text { 'Positive' } \\
3 \text { 'Somewhat positive' } \\
4 \text { 'Somewhat negative' } \\
5 \text { 'Negative' } \\
6 \text { 'Very negative' } \\
7 \text { 'Do not understand the question' } \\
9 \text { 'Decline to answer' " }\end{array}$ \\
\hline \multirow{2}{*}{$\begin{array}{l}\text { Perception } \\
\text { Gaps for } \\
\text { US } \\
\text { Positivity }\end{array}$} & IV 5 & 164 & $\begin{array}{l}\text { Does the United States } \\
\text { do more good or harm to } \\
\text { the region? }\end{array}$ & $\begin{array}{l}\text { “-1 'Missing' } \\
1 \text { 'Much more good than harm' } \\
2 \text { 'Somewhat more good than harm' } \\
3 \text { 'Somewhat more harm than good' } \\
4 \text { 'Much more harm than good' } \\
7 \text { 'Do not understand the question' } \\
8 \text { 'Can't choose' } \\
9 \text { 'Decline to answer' " }\end{array}$ \\
\hline & IV 4 & 171 & $\begin{array}{l}\text { General speaking, the } \\
\text { influence the United } \\
\text { States has on our } \\
\text { country is? }\end{array}$ & $\begin{array}{l}-1 \text { 'Missing' } \\
1 \text { 'Very positive' } \\
2 \text { 'Positive' } \\
3 \text { 'Somewhat positive' } \\
4 \text { 'Somewhat negative' } \\
5 \text { 'Negative' } \\
6 \text { 'Very negative' } \\
7 \text { 'Do not understand the question' } \\
9 \text { 'Decline to answer' " }\end{array}$ \\
\hline \multirow{2}{*}{$\begin{array}{l}\text { Perception } \\
\text { Gaps for } \\
\text { China's } \\
\text { Positivity }\end{array}$} & IV 7 & 165 & $\begin{array}{l}\text { Does China do more } \\
\text { good or harm to the } \\
\text { region? }\end{array}$ & $\begin{array}{l}\text { “-1 'Missing' } \\
1 \text { 'Much more good than harm' } \\
2 \text { 'Somewhat more good than harm' } \\
3 \text { 'Somewhat more harm than good' } \\
4 \text { 'Much more harm than good' } \\
7 \text { 'Do not understand the question' } \\
8 \text { 'Can't choose' } \\
9 \text { 'Decline to answer' " }\end{array}$ \\
\hline & IV 3 & 169 & $\begin{array}{l}\text { General speaking, the } \\
\text { influence China has on } \\
\text { our country is? }\end{array}$ & \begin{tabular}{|l}
-1 'Missing' \\
1 'Very positive' \\
2 'Positive' \\
3 'Somewhat positive' \\
4 'Somewhat negative' \\
5 'Negative' \\
6 'Very negative' \\
7 'Do not understand the question' \\
9 'Decline to answer' "
\end{tabular} \\
\hline
\end{tabular}

Source: Author's construction using the ABS Wave 4 